Raisa G. Gracheva ${ }^{1 *}$, Tengiz F. Urushadze ${ }^{2}$

${ }^{1}$ Institute of Geography of RAS, Staromonetny per. 29 Moscow 119017 Russia.

Tel. +7 495 9590028; e-mail: gracheva04@list.ru

*Corresponding author

${ }^{2}$ Ivane Javakhishvili Tbilisi State University, 3 Ilia Chavchavadze Ave. 0128 Tbilisi, Georgia. Tel. 995322908 07; e-mail: t_urushadze@yahoo.com

\title{
LANDSLIDES IN A RURAL MOUNTAINOUS REGION: DAMAGING AND RESOURCE- FORMING IMPACTS (SOUTH CAUCASUS, GEORGIA)
}

\begin{abstract}
Catastrophic loss of soils and slope sediments by landslides causes destruction of mountainous environment and outflow of population from affected areas. However, the role of landslides in mountainous regions goes beyond direct destructive activity. The sliding mass expose surfaces for weathering and accumulate loose mineral material, the vital resource for mountain biota and population thus starting new cycles in ecosystems development, forming new habitats for biota and, in some cases, new lands for farming. A chronological sequence of landslides and their adaptation for human needs was studied in Adjara province, the South Caucasus mountainous region, Georgia. As a rule, in 15 years, a thin and compacted soil layer is formed on low and mound surface of a landslide. In 30 years, people start recultivation of the landslide area. After $40-60$ years, the landslide area is used as a hayfield. It usually takes 100 years to transform the area into a fully cultivated landscape typical of Mountainous Adjara.
\end{abstract}

KEY WORDS: landslides, mountains, mass wasting, soils, the Caucasus.

\section{INTRODUCTION}

In mountainous regions, soils and loose sediments and their fine components, in particular, are the life-supporting resource for biota, as well as for the human habitat and economic activities. Slope mantle of loose material, once removed, cannot regenerate within a human life-time or even longer [Targulian, 2008]. The mountainous areas devoid of loose slope cover soon lose their population, and human history manifests a number of such examples [Messerli \& Ives, 1997; llychev \& Gracheva, 1998]. Landslides are among the most disastrous mechanisms of mass wasting and erosion in mountainous areas, causing a complete destruction of soils and regolith by their transport from hillslopes and by sealing lands under the landslide mass.

Even scattered examples show an enormous role of landslides in sediment transport and environmental change. The famous Elm landslide, Switzerland, on 11 September 1881, covered $800,000 \mathrm{~m}^{2}$ with 3-6 m thick debris. The total volume was estimated at about $0.01 \mathrm{~km}^{3}$. The landslide caused by Mount St Helens eruption, USA, 1980, had an estimated volume of $2.5-2.8 \mathrm{~km}^{3}$ and covered the surrounding area with 45-180 m layer of debris [Warburton, 2007]. One of the largest landslides ofthe past, theSaidmarrehlandslide in the Kubir Kuh Mountains, in southwest Iran, occurred about 10,000 years ago and changed land topography of the entire vast region having an exceptional volume of about $20 \mathrm{~km}^{3}$ [Shoaei \& Ghayoumian, 1998]. Hazardous mass movement may also 
affect the environment due to postponed catastrophes, such as outburst floods of lakes dammed by landslide sediments [Hewitt, 1992; Shuster \& Highland, 2007].

Landslides of different magnitudes can cause significant environmental damage. Lanslides can move large volumes of sediments from hillslopes and infringe on forest and agricultural land. Studies to estimate contributions from individual landslide events to loose sediment transport and to assess a short-term response of a 3000 ha catchment area to the intense Bola Cyclone event, 1998, performed in New Zealand [Page et al., 1999] showed that, out of the total $1.35 \mathrm{mln} \mathrm{m}^{3}$ volume of fine sediment moved during the storm, approximately $89 \%$ was from the landslide erosion on the slopes; shallow landslides were responsible for approximately $64 \%$ of the sediments at the exit from the catchment area. Even in a few years following the event, suspended sediment concentrations in waterways were $100 \%$ greater than before due to the continued erosion of landslide scars and stored sediments. Other data on soil loss can be found in quantitative assessments of losses of soil resources due to landslide activity (e.g., [Schuster \& Highland, 2007]).

Heavily populated mountainous regions suffer particularly from landslides, including extremely destructive events. However, in many mountainous regions, people that left their settlements destroyed by a disastrous landslide soon return to the damaged territory. Leaving aside economic, ethnic, and other reasons for such behavior, we have to consider the role of landslides in mountainous regions as much more complex than the apparent hazard for landscapes and humans.

In some cases, landslide deposits are spread out more or less evenly and are not completely eroded and removed by water flows. Part of sliding mass can be stopped and stabilized and it may form new elements of the mountainous topography. These are bench-like or fan-like steps on slopes, at the base of scarps or in river valleys; they store enormous volume of loose material, both coarse and fine. These landforms resulting from sliding, slumping, and other processes of mineral mass movement are found in many mountain regions and in the coastal regions in particular [Easterbrook, 1993]. With time, they may be reclaimed and used for settlements or farming, either for pastures or for crop production [Schuster\&Highland, 2007]. Some types of postponed environmental feedback to landslides (positive for humans) are described by Shoaei and Ghayoumian [1998]: the Saidmarreh landslide blocked two rivers forming lakes drained away now, and, at present, the lake sediment provides fertile farmland for the local population. This is of particular importance in densely populated mountain regions with a shortage of usable lands.

In this paper, we consider the dual role of landslides in the mountain environment and society, as a hazard to soil and slope regolith and, on the other hand, as a mechanism of local accumulation of loose mineral material usable for economic needs, with a special reference to Mountainous Adjara, in the western part of the Republic of Georgia, the South Caucasus.

\section{LANDSLIDES IN GEORGIA}

Landslide hazard is extremely high in Georgia. More than 2,000 settlements with the population of 200,000 are located in landslideprone areas, and about $70 \%$ of identified landslides occur in developed areas. During the last 50 years, particularly in the last 20 years, the number of landslides has increased dramatically. By 1960, 3,000 landslides were registered; in 1981 and in 1987-1989, there were 10,000 and 30,000 , respectively; more than 53,000 landslide events took place in 2006. Most of the landslides occurred in the mountainous regions. The number of buildings damaged by landslides increased from 384 in 1981 to 5,044 in 1988 and was 10,808 in 1990. In 1991-1992, series of earthquakes simultaneous with high rainfalls caused disastrous landslides and rockfalls in 
the mountains, which affected about 1,500 settlements ([Tzereteli, 2000]; data of official statistics of Georgia).

To assess the extent of landslide hazard, the ratio of the landslide-damaged area to the total area $\left(K=S_{\text {landslide }} / S_{\text {total }}\right)$ is usually used [Sheko, 1982].

In terms of the extent of landslide hazard $(K)$ and risk assessment, Georgia is divided into 7 zones [Tzereteli, 2000].

1. Mountains of the Black Sea coastal area with $\mathrm{K}=0.7-0.9$, extremely high risk of landslides.

2. Mountainous Adjara and the foothill belt of Guria, $K=0.5-0.7$, high risk of landslides.

3. Northern macroslope of the Trialet Ridge, the Akhaltsikhe depression and the piedmont of the South Caucasus (between the Gori and Aragvi Rivers), $K=0.3-0.5$, significant risk of landslides

4. The southern macroslope of the Greater Caucasus composed of shale rocks and flysch, alpine zone of the Trialet Ridge, $K=0,1-0,3$, medium risk of landslides.

5. The southern macroslope of the Greater Caucasus composed of volcanic and carbonate rocks, hills of the Gori upland, $K=0.01-0.1$, significant risk of rockfalls.

6. The Greater Caucasian zone composed of rocks of crystalline formations, the Javakheti volcanic upland, massifs of Khrami, Loki, and Kelasuri, $K=0.01$, significant risk of rockfalls.

7. The Colchis Lowland, Inner Kartly, no landslides.

For the study of landslides' role in populated mountainous regions of Georgia, Mountainous Adjara was selected. Adjara demonstrates particularly tight relations between population activity and dangerous natural processes.

\section{LANDSLIDES IN MOUNTAINOUS ADJARA AND THEIR RECLAMATION FOR HUMAN NEEDS}

Mountainous Adjara, or Upper Adjara, a part of the Autonomous Republic of Adjara, belongs to the western part of the AdjaraTrialet mountain system. At present, it is a densely populated region with a long history of development [Dzhaoshvili, 1968; Putkaradze, 2005]. The area is bounded by the Meskheti Ridge in the north, by the Shavsheti Ridge in the south, and by the Arsian Ridge in the east; it resembles an amphitheater of stepped configuration descending westwards and to the Adjaristskali river valley. The ridge altitudes vary from 1,000 to 2,000 $\mathrm{m}$ above sea level (asl), the highest points (mountain tops and crests) are more than 2,000 m high; the relative heights above the valley floor are about 400-600 m. The mountain slopes are steep, and rockfall slopes are widely distributed in the region, particularly at high elevations. The region is, for the greater part, is composed of Paleogene rocks with widely distributed volcanic formations, such as lava, tuffolava, tuffs, and rocks of mostly intermediate composition (andesites and andesite porphyrites). These are the areas of neotectonic uplifts intensifying erosion and mass-wasting processes. The climate of the area is wet and changes from subtropical to temperate with altitude. The mean annual precipitation is 1,000-1,600 mm. Typical, for the entire area, are summer storms, their intensity, and duration growing with altitude, and a thick snow cover in winter (up to 3-4 m). Prolonged alteration of the rocks under wet mild climate resulted in weathering crusts 3-10 m thick, clayey, loamy, and silty in composition, often with small-size debris and rock fragments.

The presence of every factor controlling sliding processes are characteristic in the region; these are steep slopes, water saturation of slope material during snow melting, frequent rainfalls, and weak slope cover consolidation due to fractured rocks and poorly cemented deeply weathered sediments [Emelyanova, 1964; Tzeretely \& 
Tzeretely, 1985]. Landslide-prone areas increase eastwards.

There are various types of landslides recorded in the region, including tectonic and shallow landslides, debris flow, earthflow, mudflow, creep, and slumps, often forming a natural landslide complex. The most active removal of loose material takes place on the steep slopes of gorges with stream channels at their base. In typical cases of undisturbed block of soil and regolith, together with forest slumping into the river (Fig. 1), loss of the material is estimated at $100-1200 \mathrm{~m}^{3}$ (personal communication with specialists of the Adjarian Geologic Survey). All forested slopes display a microrelief of shallow slumps; it is most clearly pronounced on the southfacing slopes where the sites of so-called "drunken forest" are found occasionally. The shallow landslides are distinctly seen in the soil profile. They are mostly responsible for

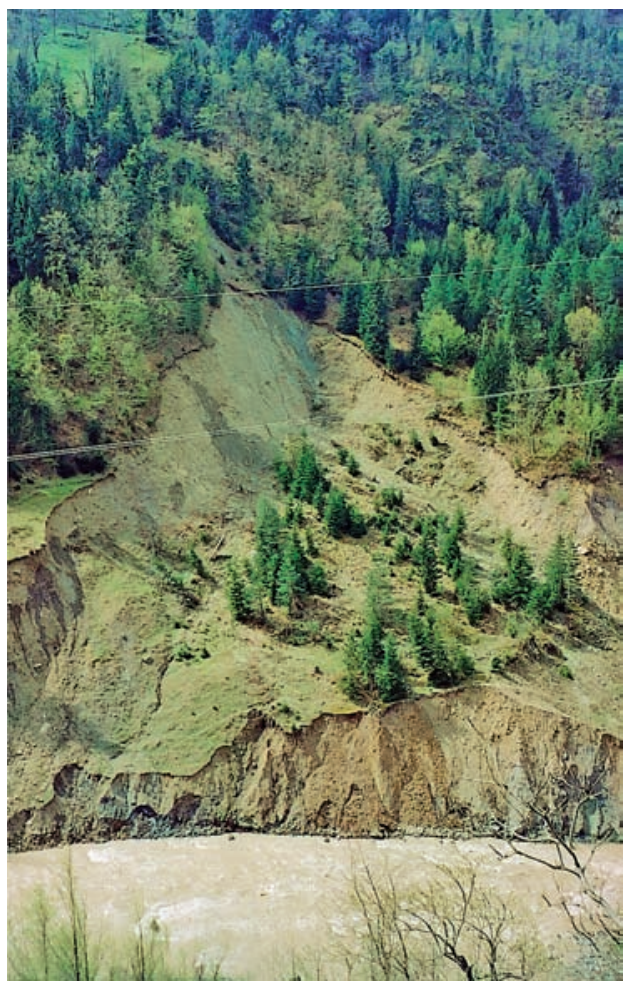

Fig. 1. A slump block breaking away from the riverbank and irreversible loss of loose slope sediments. The Adjaritskhali River, Mountainous Adjaria, Georgia buried humus horizons, or for "inverted" layers, with coarser material overlying fine soil.

Due to heavy dissection of the land surface, only $10-11 \%$ of the total Mountainous Adjara area is suitable for settlement and agricultural farming. The shortage of cultivable lands is one of the most crucial problems of this region. Many settlements are located on large bodies of regolith slowly moving downslope. In the course of centuries, the inhabitants have been adapting to the landslide hazard. Light wooden pile-supported houses do not require clearing a large building site and laying the foundation. Under land shortage, such a way of building was the most handy and relatively safe.

In the $20^{\text {th }}$ century, the human impact on the environment was increasing dramatically until the 1990s [Gigineishvili \& Nahutsrishvili, 1998; Gracheva, 2004]. The population density in the settled and cultivated areas of Keda, Shuakhevi, and Khulo municipalities grew and a network of motor roads was built, often using rock explosions. Upper Adjara was a region of profitable tobacco monoculture and with increase of the population income wooden houses were replaced with heavier structures of brick or stone that required larger sites to be cleared. Water pipes were laid to supply water to all the households and vegetable gardens; the water use, however, was not controlled and water flowed constantly onto the slopes unimpeded.

The 1980s were marked, in Mountainous Adjara, by extremely rapid snow melt and by increase in rain frequency and duration, which triggered sliding and slumping, as well as small mudflows [Berdzenishvili, 2000]. People did not pay attention to the hazard until fissures began to appear in stone walls of their houses; small slumps and slides damaged farmyards, vegetable gardens, and asphalt roads and micro-mudflows blocked water sources. Landslide aggravation may be inferred from the statistics of the residents' appeals to the state agencies, including to those responsible for property 
damage insurance. Thus, in the spring of 1988, officers of the state agencies visited several households in the Khulo district daily to record damage due to landslides and small mudflows. It is clear enough that though landslides themselves are practically unavoidable, the damage to infrastructure could be far less if better-adapted ways were used in building and road construction and in other economic activities.

In the last 20 years, under current climate changes, the socioeconomic processes act as a catalyst of natural hazards, primarily, of landslides. Single crop tobacco farming fell after the USSR breakdown and unemployment and low income lead to disregard for the nature protection rules and landslide prevention and mitigation. Soiland water-conservation forests have been subject to intensive illegal cutting, and that is a strong factor of landslide aggravation. At present, more than 250 settlements with about 20,000 households are located in the areas of high risk [Jorbenadze, 2010].

Land shortage forces people to use every available parcel of land. Geomorphological survey in the Skhalta River canyon, the northern macroslope of the Shavsheti Ridge, showed that many settlements and agricultural plots in the lower portions of the valley slopes are located on landslide deposits. A chronological sequence of three landslide bodies along the left riverbank was studied; the time interval between the landslide events was estimated using direct and indirect evidence related to a 40-60 yr time-period. The sequence is as follow:

\section{The landslide of April 15, 1988.}

2. The landslide that occurred about $60 \mathrm{yrs}$ ago (the age based on the eye witnesses' accounts and the age of the forest on the landslide, main scarp, and zone of depletion).

3. The landslide that occurred about a century ago (dated by circumstantial evidence, including age of the forest on the landslide, main scarp, and zone of depletion].

On April 15, 1988, a large mass of loose sediments slumped from the north-facing slope, impounded the river, and covered the opposite riverbank. A part of Tsablana village was buried under masses of loam and debris.

The slump was detached from the mountain slope at an altitude of about $1800 \mathrm{~m}$, the height of fall was approximately $400 \mathrm{~m}$, and the travel distance exceeded $3 \mathrm{~km}$. The river was impounded with a dam 10-15 m high. Luckily, the dam erosion proceeded at a slow rate, so no catastrophic flood happened downstream. The total volume of the landslide composed mostly of mixed rock fragments, rubble, and clay was roughly estimated at $20 \times 10^{4} \mathrm{~m}^{3}$. About a half of the volume got into the river and was washed down; some material was moved to the river later, in the process of erosion followed.

Fifteen years later, in 2003, the remnants of the landslide mass deposited at the base of the slope became a cone-shaped body, partly forested, its surface bearing low transverse ridges, hollows infilled with sand and clay, as well as with individual large rock fragments and tree debris (Fig. 2). On the riverbank, there is a distinct line of initial surface buried under the sliding mass; it may be seen that deposits of the landslide toe are unstable and are being eroded by overland flow. The uppermost $5 \mathrm{~cm}$ of deposits consisting of mixed small debris and loam with coarse organic matter may be regarded as the initial stage of soil formation. Below the deposits, there are sand, loams, and clay more densely packed and even cemented into non-sorted mixture of rubble, with occasional fragments of solid rocks. As the slope mantle was initially deeply weathered, the debris can be easily crumbled in hands into sandy loam or clay. The landslide scarp has open surface and the zone of depletion is sparsely vegetated; at the time of rain, they yield fine material washed downslope onto the surface of the landslide body. 


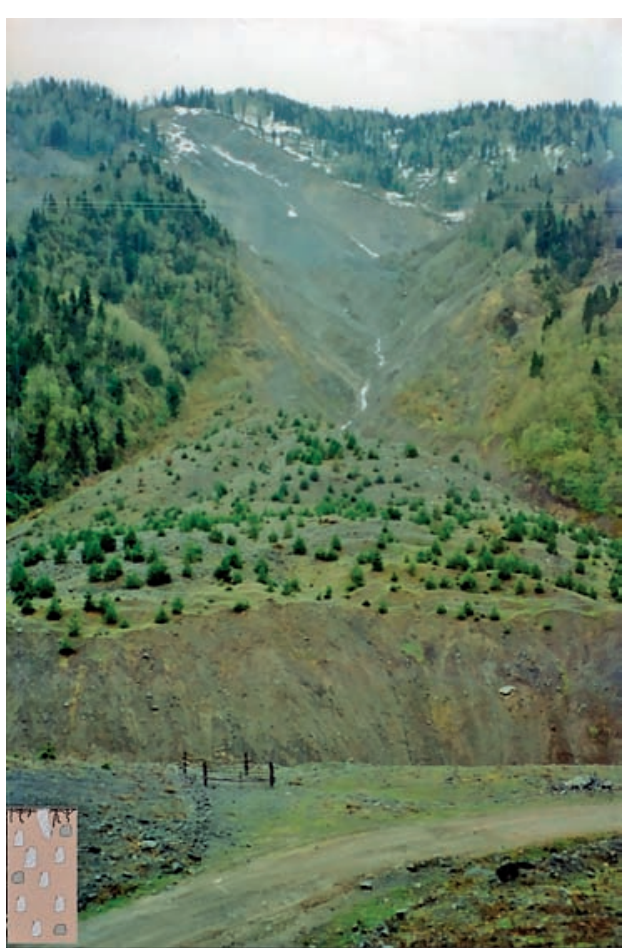

Fig. 2. The 15-yr old landslide (the photo taken in 2003). The Skhalta River valley, Mountainous Adjaria, Georgia Insertion in the left corner: initial soil profile, stony-loamy non-graded mineral matter

The second, more recent, investigated landslide is located downstream on the same side and topographic position in the Skhalta valley (Fig. 3). It is similar to the abovedescribed landslide in size and configuration, though its surface is more flattened and covered with coniferous forest. In the lower flat portion of the landslide, the forest was clear-cut and the area was converted into a hayfield. Stones removed from the surface and topsoil were piled up in heaps and the surface was repeatedly ploughed and sown with perennial grasses. According to the local residents, the landslide surface recultivation began about 20 years after the event and took approximately 10 years. Stones have to be removed from the area continuously.

As has been shown by field studies, there exists a relatively well developed soil, with a structured humus horizon up to $10 \mathrm{~cm}$ thick and a $30-40 \mathrm{~cm}$ thick loam horizon; the latter contains debris in small proportion and is penetrated by grass roots. The soil granulometric composition has been altered by farming in order to create favorable soil conditions for the hayfield and in the course of general agricultural landscape development.

The tip of the landslide body is overhanging the river, so the area may be considered landslide-hazardous. The surfaces of the landslide scarp and the zone of depletion are all forested but for several steep scarps; on the slope above the hayfield, under the forest canopy, there are accumulations of stones transported probably from the scar surface.

The landslide of about 100-yr estimated age is located still farther downstream; it is identical to the landslide described above in topographic position and is located on the same riverbank (Fig. 4). Its tongue has

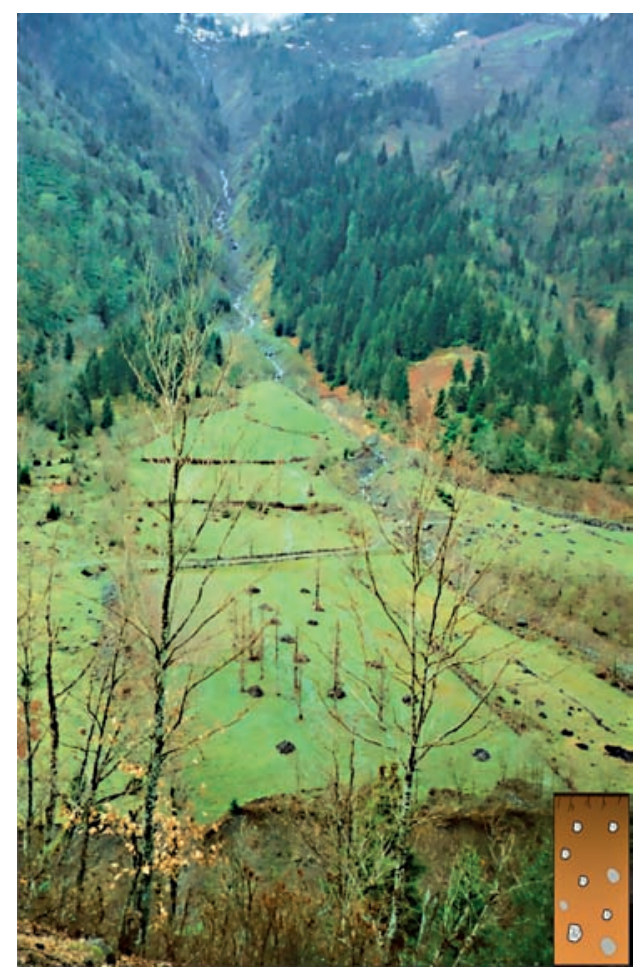

Fig. 3. The landslide of about 60 years age; reclaimed for a hayfield. Insertion in the right corner: newly reclaimed soil profile $(50 \mathrm{~cm})$; humic (mull-moder) A horizon, sandy gravel loamy subsoil 

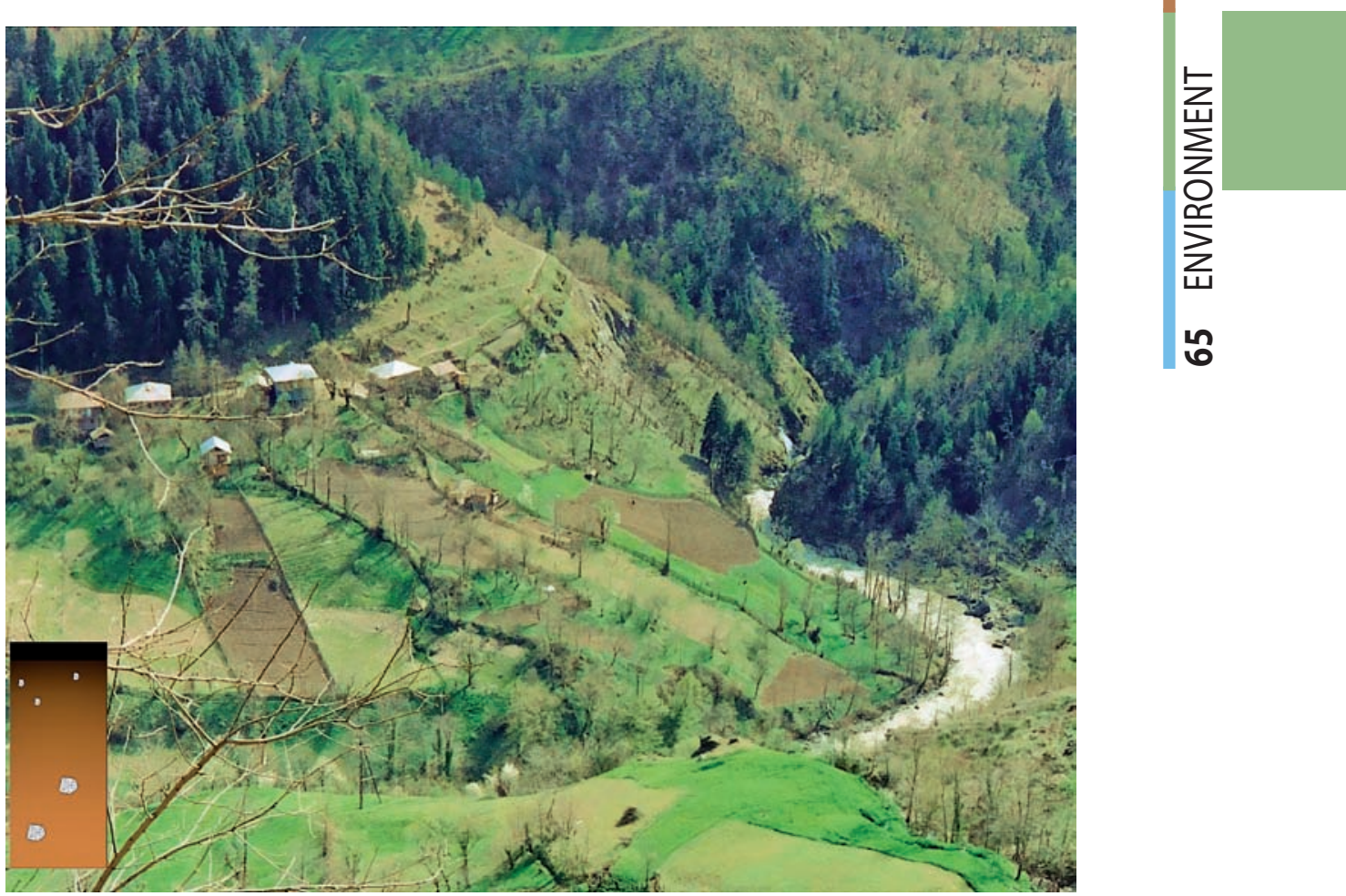

Fig. 4. The landslide of 100 -yr estimated age (or older); developed area and farmland. Insertion in the left corner: reclaimed soil profile $(50 \mathrm{~cm})$; humic (mull) aggregated A horizon, fine gravel - loamy subsoil

reached the river and the landslide itself is almost undistinguished against the slope background. The main scarp is forested with some open surfaces; the zone of depletion is completely forested. The landslide surface, except for its lowermost part, is covered completely with thick coniferous forest. The lower part presents a cultivated landscape typical of Mountainous Adjara (residential buildings, vegetable gardens, orchards, etc.).

At the cultivated part of the landslide, soils consist of a thick (up to $20-30 \mathrm{~cm}$ ) humus horizon underlain by a loamy horizon, reaching $60 \mathrm{~cm}$ or more and bearing all the signs of alteration by pedogenic processes. The soils are very fertile because of abundance of nutritional minerals supplied by debris weathering and fertilization.

Local residents and authorities explain that the described plots are very suitable for settling and cultivating. Before the event, there were steep forested mountain slopes quite unsuitable for farming and development. The landslides created landforms with relatively gentle slopes and, which is even more important; they accumulated great masses of loose material - a valuable agricultural resource in mountains. Twenty to thirty years after the event, the landslide surface solidified; its sides spread laterally and became gentler. Residents of mountainous regions have become quite accustomed to stone removal from the fields for many centuries, so this does not represent a problem for their activities. Approximately 40 years after the event, the catastrophe is forgotten and the landslide surface is used for residential development and agriculture. The land is regarded as top-quality and, under the shortage of cultivable lands, its origin is not a concern.

There are many other regions of the Caucasus where landslides have been long used for agriculture. Thus, landslide bodies were used for 
slope development into agricultural terraces in the central part of the North Caucasus, in North Jurassic intermountain depression, where the slopes are composed of schist. As a rule, people use small slumps when almost undisturbed blocks of regolith move and form bench-like steps. People level slump surface, reinforce its base, and use it for growing crops. The slopes transformed in this way are usually resistant to surface wash and erosion, though repeated sliding and slumping cannot be excluded. Terrace steps are identifiable as landslides by preserved scarps upslope. Another evidence of their origin is buried soil preserved locally under the terrace body. In case of a buildup terrace, not resulting from slumping, the original surface soil is usually disturbed.

Studies of soils and deposits buried under landslides allow the event to be dated; besides, they provide insight into environments of the past and the history of the region settlement. The material brought downslope by slumping and sliding covers settlements and makes people leave their territory; at the same time, it seals and preserves information on the past environments and historical events, if it has such a magnitude that the buried surface is preserved and could be discovered later on [Gracheva \& Golyeva, 2010].

\section{CONCLUSION}

Being a part of the global process of the earth surface denudation, transport of loose material by landslides is of vital importance for particular mountainous areas, their environments, and the population. Such consequences as destruction of cultivated lands, houses, and infrastructure require great efforts for damage compensation. Another consequence is irrecoverable loss of loose material, soils, and their most important constituent - fine earth. Eventually, this loss results in a dramatic reduction of biodiversity, ecosystem productivity, depopulation of the territory, and its turning into badlands. There is information on loose material losses for many landslide events in the world. It is possible to calculate the volume of the lost fine earth washed away by rivers; such calculations have been already performed, though for only few cases. But it is still uncertain whether it is possible to forecast environmental evolution and social development in mountainous regions under catastrophic loss of soil and regolith from vast areas.

It should be noted, however, that the landslide role in mountainous regions extends beyond destructive activity and removal of soil and regolith. By transportation and deposition of loose material, landslides promote rejuvenation of mountainous ecosystems and development of new soils, as well as creation of new sites for settlement. New surfaces become exposed to weathering and new landforms emerge forming new habitats for biota and, thus, starting new cycles in ecosystem development. Stabilized landslide deposits provide a potential resource of loose mineral material and the newly formed landforms are being adapted to the needs of the people.

The case study of a chronological sequence of landslides in the Adjara-Trialet mountainous system presented herein shows that people can colonize and cultivate landslide accumulations within a few decades. Fifty to sixty years after the event, sediments appear to be essentially altered by remediation measures and the resulting soils are suitable for agriculture. This is of great importance in the region deficient in cultivable lands. Thus, the landslide process implies potential for long-term recovery from rapidly inflicted damage.

\section{ACKNOWLEDGMENTS}

The authors extend their sincere gratitude to the colleagues from Georgia: Acad., Prof. V.P. Tsanava, General Director of the Research Institute for Tea, Subtropical Cultures and Tea Industry, Anaseuli; geologists of the Department for Geology and Mining of the Autonomous Republic of Adjara, and staff of the Khulo district Land Department for their assistance and for providing information. The research in Georgia would not be possible without goodwill and hospitality of the local administration and numerous farmers of the Skhalta municipality. 


\section{REFERENCES}

1. Berdzenishvili D. (Ed.) (2000). Information bulletin of ecological state of groundwater, studies of hazardous geological processes and their forecast. Georgian State Department of Geology, Tbilisi. 412 pp. (In Georgian).

2. Dzhaoshvili V. Sh. (1968). Population of Georgia. Metsnieroba, Tbilisi. 397 pp. (In Russian).

3. Easterbrook D.J. (1993). Surface Processes and Landforms. Macmillan Publishing Company, New York, NY. 520 p.

4. Emelyanova E.P. (1964). The main patterns of landslide processes. Nedra, Moscow. 333 pp. (In Russian).

5. Gigineishvili G.N., Nahutsrishvili G.Sh. (1998). Problems of sustainable development of the mountainous regions of Georgia). Bulletin of the Russian Academy of Sciences. Geography Series, 6, 95-101(in Russian).

6. Gracheva R.G. (2004). Land use transformation in Mountainous Adzharia and its possible consequences (the last 15 years). Annals of Agrarian Science, 4, 7-15 (in Russian).

7. Gracheva R.G., Golyeva A.A. (2010). Landslides in Mountain Regions: Hazard, Resource, Information. In: Beer T. (Ed.) Geophysical Hazards. International Year of Planet Earth. Springer, 249-260.

8. Hewitt K.K. (1992). Mountain hazards. GeoJournal, 27, 47-60.

9. Jorbenadze T. (2010). Adjara Eco-Migrants and State Policy. http://en.iod. ge/?mod=articles\&rubric $=2 \& i d=11$

10. Ilychev B.A., Gracheva R.G. (1998). Conditions of loose mantle of mountainous regions as a factor of their sustainable development. Bulletin of the Russian Academy of Sciences. Geography Series, 6, 48-59 (in Russian).

11. Messerli B., Ives J.D. (Eds.) (1997). Mountains of the World. A Global Priority. Parthenon Publishing, New York and Carnforth. 495 pp.

12. Page M.J., Reid L.M., and Linn I.H. (1999). Sediment production from Cyclone Bola landslides Waipaowa catchment. Journal of Hydrology (New Zealand), 38 (2), 289-308.

13. Putkaradze T. (2005). Migration of population of Adjara and ethno-demographic problems in multiethnic region. Batumi University, Batumi. 205 pp. (In Georgian).

14. Schuster R.L., Highland L.M. (2007).Overview of the Effects of Mass Wasting on the Natural Environment. Environmental and Engineering Geoscience, 13(1), 25-44.

15. Sheko A.I. (1982). Theory and methods of forecasting exogenous geological processes. In: Sheko A.I. (Ed.) Landslides and Mudflows. Center for international Projects, the State Committee for Science and Technology, Moscow, 361-378. (in Russian). 
16. Shoaei, Z., Ghayoumian, J. (1998). Seimareh landslide, the largest complex slide in the world. In Proceedings Eight International Congress of the International Association for Engineering Geology and the Environment, 1-5, pp. 1337-1342.

17. Targulian V. (2008). Soils and society: human impact and soil responses. In: Dazzi C., Costantini E. (Eds.) The soils of tomorrow. Soils changing in a changing world. Advances in GeoEcology, 39, 13-26.

18. Page M.J., Reid L.M., and Linn I.H. (1999). Sediment production from Cyclone Bola landslides, Waipaowa catchment. Journal of Hydrology (New Zealand), 38 (2), 289-308.

19. Tzereteli E. D. (2000). Elemental Nature Phenomena. In: Geography of Georgia. Part I, Physical Geography, "Metsniereba", Tbilisi, 69-83 (in Georgian).

20. Tzeretely E.D., Tzeretely D.D. (1985). Geological setting of mudflows in Georgia. Metsniereba, Tbilisi. 188 pp. (In Russian).

21. Warburton J. (2007). Mountain environments. In: Perry C., Taylor K. (Eds.) Environmental sedimentology. Blackwell Publishing, 32-74.

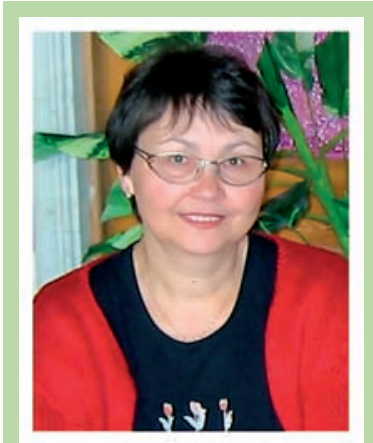

Raisa G. Gracheva, PhD, graduated from the Faculty of Geography, Department of Landscape Geochemistry and Soil Geography, Moscow State University. Currently, she is leading scientist of the Institute of Geography of RAS. Her fields of interests are mountain soils, hydromorphic soils, and interactions between mountain population and the environment.

Selected publications: Gracheva, R.G., M.L. Kozeltsev. Agenda for Mountainous Settlements of the Caucasus. M., MediaGrouplnform, 2009. 125 p. Vandenberghe, J., R. Gracheva, A. Sorokin. Postglacial floodplain development and MesolithicNeolithic occupation in the Russian forest zone. Proceedings of the Geologists' Association 121 (2010) 229-237. Gracheva, R. Formation of soil diversity in the mountainous tropics and subtropics: Rocks, time, and erosion. Geomorphology (2011), doi:10.1016/j.geomorph.2011.02.008.

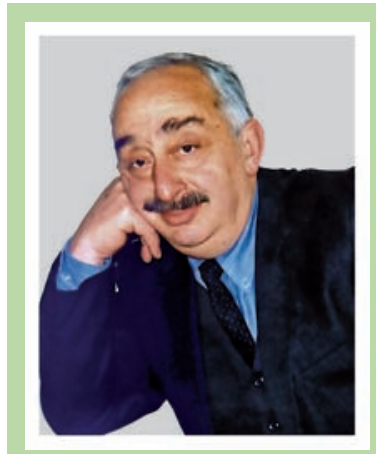

Tengiz F. Urushadze, Prof., graduated from the Georgian State Agrarian University, received his Doctor of Science degree in pedology from Moscow State University (1979). He was Head of the Chair of Soil Science, Provost, and President of the Georgian State Agrarian University. Currently, he is full professor of the Ivane Javakhishvili Tbilisi State University. From 1985 to present, President of the Georgian Soil Science Society (GSSS). His primary fields of scientific interests are soil genesis and soil protection. Author of more than 350 publications, including about 30 monographs and textbooks.

Selected publications: Mountainous Soils of the USSR. Moscow, Agropromizdat, 1989 (in Russian); Soil map of Georgia. Metzniereba, 1999 (editor); Andosols of Georgia. Tbilisi, 2009 (in Georgian); Thermal regime of some types of soil in Georgia, Pochvovedenie, 2010, 4 (in Russian). 